\title{
Dariusz Kasprzak
}

Uniwersytet Papieski Jana Pawła II w Krakowie

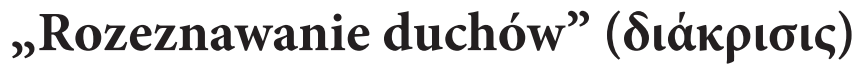 w czasie monastycyzmu patrystycznego}

\section{Wprowadzenie}

W opisach życia duchowego, jakie z okresu patrystycznego przetrwały do naszych czasów, możemy odnaleźć liczne wzmianki o władzy

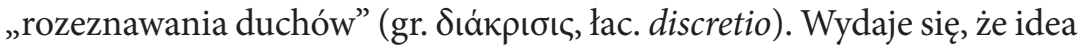
ta została przemyślana i była praktykowana przede wszystkim w antycznym monastycyzmie, dlatego to on wyznacza merytoryczny zakres tego

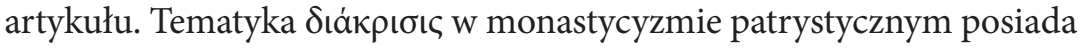
bogatą literaturę przedmiotu, by wspomnieć najważniejsze opracowania, których autorami byli G.M. Colombás, A. Guillaumont, I. Hausherr, M.R. Jurando, W. Misijuk, L. Nieścior, A.D. Rich i T. Špidlik. Wstępnie, odwołując się także do studiów przytoczonych badaczy, postaram się dać swoją syntezę tego zagadnienia. Po rozważeniu, czym było „roze- 
znawanie duchów" wokresie patrystycznym, chciałbym przejść do omówienia celu tej władzy, określających ją warunków i kryteriów koniecznych, kwestii otwartej: snów i wizji jako rzeczywistości trudnej do oceny władzą „,rozeznawania duchów” oraz aspektu subiektywnego i obiektywnego w procesie „rozeznawania duchów”.

\section{Czym było rozeznanie duchów w okresie patrystycznym?}

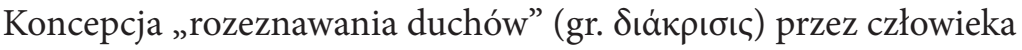
wierzącego była obecna już w tekstach z Qumran', u św. Pawła Apostoła $^{2}$, w apokaliptycznym Pasterzu Hermasa ${ }^{3}$ oraz w alegorycznych komentarzach biblijnych Orygenesa ${ }^{4}$. Natomiast tymi, którzy opraco-

${ }^{1}$ Por. G. Dautzenberg, Zum religiongeschichtlichen Hintergrund der „diakriseis pneumaton“ (1 Kor 12,10), „Biblische Zeitschrift” 15(1971), s. 93-104; J.L. Duhaime, L'instruction sur les deux esprits et les interpolations dualistes à Qumrân (1 QS III,13-IV,26), „Rivista Biblica“ 4(1977), s. 566-594; D.C. Allison, The Autorship of 1 QS III,13-IV,14, „Revue de Qumrân“ 38(1980), s. 256-268.

${ }^{2}$ Por. A. Munzinger, Discerning the Spirits. Theological and Ethical Hermeneutics in Paul, Cambridge 2007.

${ }^{3}$ W Pasterzu autorstwa Hermasa rozeznawanie jest odnoszone do uczucia niecierpliwości, do dobrych i do fałszywych proroków, do dobrych i złych pragnień i pożądań. Jak odnotowuje M.R. Jurando [Rozeznawanie duchowe. Teologia. Historia. Praktyka, przekł. K. Homa, Kraków 2002, s. 73-74] język tej łacińskiej apokalipsy z II w. nie jest jednoznaczny, stąd trudno rozpoznać, czy jej autor w każdym przypadku mówi o Duchu Świętym jako Osobie, czy o Jego działaniu w człowieku, czy też o skutkach Jego działania. Hermas ukazuje człowieka w ograniczeniach, do których zalicza także wpływ dobrych i złych duchów. Duchy oddziaływają na myśli, uczucia i namiętności ludzkie, natomiast od człowieka zależy, jakiemu duchowi da się poprowadzić w dokonywanym wyborze. Por. N.I. Fredrikson, L'esprit saint et les esprits mauvais dans le Pasteur d'Hermas: sources et prolongements, „Vigiliae Christianae” 55,3(2001), s. 262-280.

${ }^{4}$ Orygenes w kwestii rozeznawania duchów wskazywał najpierw, aby nie ulegać pokusom do złego przychodzącym z zewnątrz, następnie na umiarkowanie w zaspokajaniu naturalnych potrzeb, dalej na pomoc ze strony Boga (Najwyższy zawsze jest gwarantem, że można wygrać z pokusami) oraz na rozpoznawanie działania dobrego ducha (zawsze respektuje on ludzką wolność, nie narzuca dobra, ale je proponuje, nie niepokoi, nie zniewala ani nie drażni) bądź złego ducha (jest ono zawsze ograniczone 
wali praktyczne reguły rozeznawania duchów, byli przede wszystkim pierwsi mnisi chrześcijańscy. Rozeznawanie to stanowiło fundamentalny element duchowości pierwotnego monastycyzmu chrześcijańskiego. Mnich, którego życie było często pojmowane jako niewidzialna wojna, powinien umieć rozróżniać pomiędzy duchami dobrymi, które mu pomagają, oraz duchami złymi, szukającymi jego zguby. Rozeznawanie duchów było zatem sztuką, którą mnich posiadł przez życie w samotności, gdyż jego jedynym towarzystwem były przede wszystkim rzeczywistości duchowe. To sztuka duchowa, która miała wiele stopni: to roztropność wiodąca do Boga, to zdolność rozróżniania rzeczywistości duchowych. W stopniu najwyższym była ona uznawana za dar Boży, uzyskany jako charyzmat, który mnich otrzymywał od Boga po długim procesie oczyszczenia wewnętrznego, i o który prosił Boga wielokrotnie. Rozpoznawanie duchów było związane z zachowywaniem prawa miłości Boga i bliźniego oraz przykazań, a także owocem długiej obserwacji i rozróżnienia myśli. Rozeznawanie duchów stanowiło zatem zarówno skutek, jak i znak specjalnej obecności Ducha Świętego w doświadczonym mnichu. Stąd była ona znakiem praktycznych mistrzów duchowych, jakimi byli egipscy święci mnisi pustyni: św. Paweł z Teb $(† 341)$, św. Pachomiusz Starszy († 346), św. Antoni Wielki (†356), św. Makary Wielki ze Sketis († 390), św. Pimen Wielki z Terenuthis $(\dagger 450)$ czy św. Szenute z Atripe († 451/466). Przez swą charyzmatyczną posługę rozeznawania duchowego byli oni nazywani „nosicielami

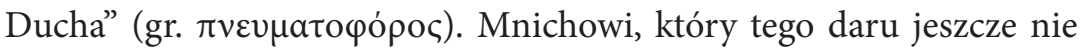

Bożym przyzwoleniem do danej próby, zły duch zmierza do pozbawienia człowieka wolności wyboru i myślenia, działa przez kuszenie i pokusy, przez zewnętrzne okazje i pobudzanie do niepokoju, gniewu i rozpaczy, wreszcie przez opętanie). Więcej zob.: L. Lies, Die Lehre der Unterscheidung der Geister bei Origenes und Ignatius von Loyola, „Origeniana” 7(1999), s. 717-732; H. Pietras, Rozeznawanie duchów u Ojców Kościoła, [w:] Rozeznawanie duchów w „Ćwiczeniach duchownych”, red. K. Osuch, CzechowiceDziedzice 1991, s. 61-64; H. Pietras, Rozeznawanie duchów u Orygenesa, „Życie Duchowe" 39(2004), s. 113-116. 
otrzymał, pozostawało prosić o radę swoich duchowych ojców i podporządkować się ich przewodnictwu ${ }^{5}$.

Rozeznawanie duchów w okresie wczesnego monastycyzmu było zatem w swej istocie charyzmatem słowa, związanym $\mathrm{z}$ konkretną osobą doświadczoną w życiu duchowym ${ }^{6}$. Charyzmat słowa zanikł jako wynik zwyrodnienia praktyki życia monastycznego, prowadząc do osłabienia i utraty tego i innych charyzmatów. Charyzmat słowa zanikł, ponieważ słów Ojców pustyni już nie słuchano i nie stosowano się do nich. Z charyzmatem słowa działo się zatem podobnie jak z zanikiem charyzmatu prorockiego, czy to w tradycji żydowskiej (zanikł po prorokach Zachariaszu i Malachiaszu), czy wczesnochrześcijańskiej (zanikł na przełomie I i II w.). Ciągłość pierwotnego przekazu natchnionych słów Ojców zapewnił natomiast pisemny przekaz w postaci apoftegmatów. Ojcowie pustyni (np. z V-VIII w.) nie byli już nazywani „nosicielami Ducha”, ale tymi, którzy byli „zwiastunami słowa” i „przekazicielami słowa”. Późniejszy monastycyzm odziedziczył doktrynę o rozeznawa-

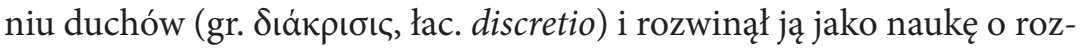
poznawaniu duchów i podjęciu decyzji oraz o konieczności rozeznania impulsów pochodzących z własnej natury ${ }^{7}$.

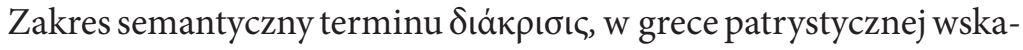
zuje na władzę „rozpoznawania”, „rozsądzania” czy też „właściwego osądu”. W tradycji ascetycznej monastycyzmu okresu patrystycznego

${ }^{5}$ Por. G.M.B. Colombás, Discernimento degli spiriti (diacrisis), [w:] Dizionario degli Istituti di Perfezione, vol. III, red. G. Rocca, Roma 1976, s. 705-706; J.T. Lienhard, On "discernment of spirits” in the early Church, „Theological Studies” 41/3(1980), s. 505-529; I. Hausherr, Spiritual Direction in the Early Christian East, Kalamazoo (MI) 2010, s. 81.

${ }^{6}$ Por. W. Harmless, Chrześcijanie pustyni. Wprowadzenie do literatury wczesnego monastycyzmu, przekł. M. Höffner, Kraków 2009, s. 194-198.

${ }^{7}$ Por. A. Guillaumont, Nauczanie duchowe egipskich mnichów. Kształtowanie się tradycji, [w:] A. Guillaumont, U źródeł monastycyzmu chrześcijańskiego, t. 2, ŹM 38, przekł. S. Wirpszanka, Kraków 2006, s. 106-107; W. Harmless, Chrześcijanie pustyni, s. $287-292$.

${ }^{8}$ Por. G.W.H. Lampe, A Patristic Greek Lexicon. With Addenda et Corrigenda, Oxford 1991, s. 354. 
przypisano mu co najmniej cztery znaczenia: rozróżnienie pomiędzy dwoma sposobami działania; wgląd w myśli innych ludzi, rozróżnienie duchów oraz roztropność. W zależności od stopnia nasilenia tej władzy ukształtowała się też w późnym monastycyzmie hierarchia ojców du-

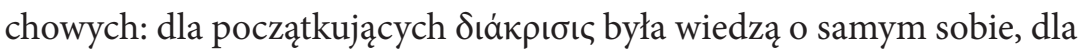
średniozaawansowanych był to duchowy rozsądek, prowadzący do bezbłędnego rozróżnienia pomiędzy dobrym i złym, dla doskonałych był to Boży dar wiedzy, pozwalający im dostrzec u innych to, czego tamci

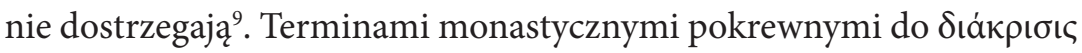

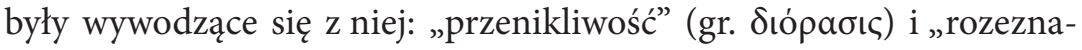

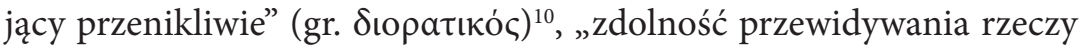

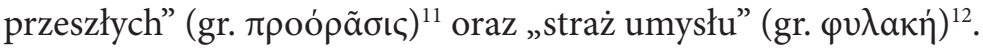

\section{Cel rozeznawania duchów}

Zdolność rozeznawania duchów była ważna dla mnichów, gdyż wnętrze człowieka, opisywane według greckiej antropologii filozoficznej jako dusza, stanowi miejsce zmagań różnych tendencji, pochodzących zarówno od samego człowieka, jak i od Ducha Świętego czy aniołów, ale także od złych duchów. Ludzkie postrzeganie tych rzeczywistości duchowych jest utrudnione przez grzech. Wspomniane inspiracje do działań pojawiają się w duszy czy to jako myśli, czy złożone wyobrażenia. Zdaniem Ewagriusza z Pontu († 399) celem rozeznania duchów jako władzy duchowej jest zatem przewodzić w walce z przeciwnościami wewnętrznymi, wspomagać cnoty, przeciwstawiać się

${ }^{9}$ Por. I. Hausherr, Spiritual Direction in the Early Christian East, s. 91-92; A. Guillaumont, "Serce” u starożytnych greckich pisarzy ascetycznych, [w:] A. Guillaumont, U źródeł monastycyzmu chrześcijańskiego, t. 2, ŹM 38, przekł. S. Wirpszanka, Kraków

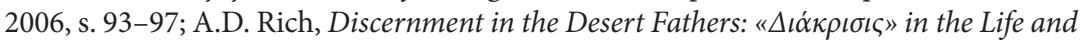
Thought of Early Egyptian Monasticism, Milton Keynes (UK) 2007.

${ }^{10}$ Por. G.W.H. Lampe, A Patristic Greek Lexicon, s. 373.

${ }^{11}$ Por. H.G. Liddell, R. Scott, Greek-English Lexicon. With a Revised Supplement, Oxford 1996, s. 1492-1493.

${ }^{12}$ Por. G.W.H. Lampe, A Patristic Greek Lexicon, s. 1492. 
wadom oraz decydować o rzeczach moralnie obojętnych (O praktyce ascetycznej 89). Dzięki całkowitemu uwolnieniu umysłu z nieczystych wyobrażeń możliwe jest przedstawienie tak przygotowanego umysłu Chrystusowi i osiągnięcie stanu ảंáacıa utożsamianego przez tego autora $\mathrm{z}$ „czystością serca” (List 52, 6; O Psalmie 17, 21) ${ }^{13}$. W ujęciu moralnym, jako słuszną miarę - umiarkowanie (łac. discretio), opisuje rozeznawanie duchów Jan Kasjan (†435). Jej celem jest dojście do właściwego usposobienia duchowego i do doskonałej kontemplacji. Dzięki discretio, rzadziej określanemu przez Jana Kasjana jako concilium, sapientia czy też sensus, mnich powinien odróżniać nałogi od cnót, to co pochodzi od Boga, od tego co jest od diabła (Instytucje życia cenobickiego 8,10$)^{14}$. Podobnie pojmowana władza rozeznawania duchów stała się w opisie ascetycznym Jana Klimaka († 579/649) właściwym wyborem moralnym, dokonywanym w duszy i związanym z czystością postrzegania i z nieskalanym sumieniem (Drabina do raju 26, 3) ${ }^{15}$.

\section{Warunki konieczne do rozeznawania duchów}

Władza rozeznawania duchów, pojmowana zarówno jako dar Boży, a także jako cnota ascetyczna, była procesem duchowym, do którego mnich powinien się przygotowywać i wewnętrznie dojrzewać. Pierwszym i nieodzownym warunkiem było proszenie Boga o udzielenie tego charyzmatu (Ewagriusz z Pontu, List 4, 5). Jak zaznaczali późniejsi systematycy życia monastycznego (np. Jan Klimak, Drabina do raju 4, 3; Jan Kasjan, Rozmowa 2, 16), mnich chcący posiąść władzę rozeznawania myśli winien odznaczać się postawami, które umożliwiają oczyszczanie serca i umysłu, czyli: posłuszeństwem (gr. úđakoฑ่) i pokorą

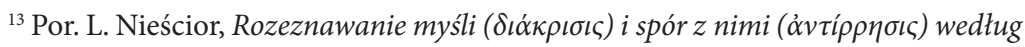
Ewagriusza z Pontu, [w:] Droga doskonałości chrześcijańskiej w epoce patrystycznej. Zagadnienia wybrane, red. J. Pałucki, M. Szram, Lublin 1997, s. 31.

${ }^{14}$ Por. M.R. Jurando, Rozeznawanie duchowe, s. 77.

15 Por. W. Misijuk, Przewodnictwo duchowe w monastycyzmie prawosławnym, Lublin 2014, s. 167. 


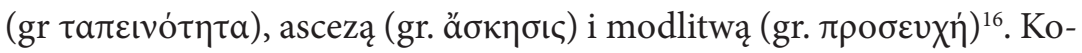
lejnymi nieodzownymi kryteriami dla doświadczenia „rozpoznawania duchów" było zachowywanie przykazań Bożych, w tym postawy miłości (Atanazy z Aleksandrii, Żywot Antoniego 22). Rozpoznanie duchów było też niewątpliwie efektem długiej obserwacji, jaką mnich musiał prowadzić nad myślami, aby odróżnić anielskie czy ludzkie od tych diabelskich. Te ostatnie często objawiają się przez myśli kuszące do popełniania jakiegoś zła (Ewagriusz z Pontu, O praktyce ascetycznej 43, 51) ${ }^{17}$.

$\mathrm{Na}$ poziomie swoistych psychologicznych reguł, które pomagają w rozpoznawaniu duchów, starożytni autorzy ascetyczni uwypuklali rozróżnienie stanu „pocieszenia” od „rozpaczy”. Antoni Wielki podał złotą regułę rozpoznania duchów:

„Przy ataku zaś złych duchów i przy wzbudzających niepokój zjawiskach mamy do czynienia z wrzaskiem, krzykiem i dzwonieniem, jakby to był zamęt wywołany przez nieokrzesanych chłopaków i rozbójników. $\mathrm{Z}$ tego rodzi się natychmiast niepokój duszy, nieład i zamieszanie myśli, wstyd, nienawiść do ascetów, niedbałość, smutek, wspomnienie bliskich i strach przed śmiercią, a potem pragnienie tego, co złe, lekceważenie cnoty i niestałość. Gdy więc, mając widzenie, przestraszycie się, ale strach ten natychmiast odejdzie, a zamiast niego pojawi się radość niewysłowiona, spokój myśli i to wszystko, o czym mówiłem wcześniej, męstwo i miłość do Boga, bądźcie odważni i módlcie się. Radość i spokój wskazują na obecność świętości. Tak też uradował się Abraham na widok Pana i Jan na widok Bożej Rodzicielki Maryi „podskoczył z radości”. A jeśli w czasie widzenia powstaje strach i wrzawa z zewnątrz, i widzenie rzeczy światowych, i groźba śmierci, i to, o czym wcześniej opowiadałem, wiedzcie, że to atak złych duchów"18.

${ }_{16}$ Por. W. Misijuk, Przewodnictwo duchowe w monastycyzmie prawosławnym, s. $176-179$.

${ }^{17}$ Por. T. Špidlik, Duchowość chrześcijańskiego Wschodu. Przewodnik systematycz$n y$, przekł. L. Rodziewicz, Kraków 2005, s. 312.

${ }^{18}$ Atanazy z Aleksandrii, Żywot św. Antoniego 36, Źródła Monastyczne 35, przekł. E. Dąbrowska, Kraków 2008, s. 104-105. 
Wydaje się, że Antoni Wielki, kiedy mówił o rozpoznawaniu dobrych i złych duchów (Żywot św. Antoniego 36-37), wskazywał na przeciwieństwo, że zjawiska anielskie są „drugą naturą”, natomiast zjawiska demoniczne zaburzają naturalny, dobry porządek. Powyższa reguła z czasem została uproszczona do twierdzenia: „Cokolwiek wzbudza niepokój, jest z diabła”. Ewagriusz z Pontu, omawiając różne kategorie myśli, które podsuwają demony (O praktyce ascetycznej 51), mówił natomiast o „stanie pokoju” i o „stanie zamętu” (O praktyce ascetycznej 80). Diadoch z Fotike ( $† \mathrm{~V}$ w.) zdawał sobie sprawę z faktu, że rozróżnienie „pocieszenia” od „rozpaczy” może być niewystarczające, gdyż szatan jest oszustem i podsuwa umysłowi odczucia fałszywej słodyczy (Sto rozdziałów o doskonałości duchownej 31). Dlatego zdaniem Grzegorza z Nazjanzu († 390) nawet jeśli diabeł przyjmuje postać anioła światłości, to jest to pozorność, którą można rozpoznać po skutkach diabelskiego działania. Jest to możliwe, gdyż człowiek, będąc stworzeniem na obraz Boży, może rozpoznać w sobie samym podobieństwo do Boga lub jego brak (Wiersz 2, 1, 83; Mowa 40, 10). Stąd mnichów napominano, by zwracali uwagę na słabe punkty w ich rozwoju według cnót czy też na jakiś brak umiaru w ascezie. Zdaniem ascetów pustyni zaniedbania w cnotach stają się punktem, od którego diabeł zaczyna osłabiać duszę (Ewagriusz z Pontu, O praktyce ascetycznej 44). Natomiast przez doprowadzenie kogoś do postawy skrajnej ascezy diabeł stara się odwrócić uwagę człowieka od czynienia tego, co możliwe, a przymusza go do czynienia to, co niemożliwe (Ewagriusz z Pontu, O praktyce ascetycznej 40) ${ }^{19}$.

\section{Pytania otwarte i niejasności w kwestii rozeznania: sny i wizje rzeczywistością trudną do oceny duchowej}

Dwuznaczność przy rozeznawaniu tego typu rzeczywistości była niewątpliwie uwarunkowana w III czy IV w. historycznie. Religijność

\footnotetext{
${ }^{19}$ Por. T. Špidlik, Duchowość chrześcijańskiego Wschodu, s. 313-314.
} 
i mistyka hellenistyczna w zamian za sprawowane obrzędy ku czci jakiegoś bóstwa, za ponoszone trudy i ascezę - oczekiwała na objawienie przez owe bóstwa jego tajemnic. Zdaniem André-Jeana Festugière ukazuje to podstawowy kontrast pomiędzy mistyką hellenistyczną a chrześcijańską. Ta druga zachęcała do walki z myślami nieczystymi, które oddzielają od Boga i stanowią przeszkodę w kontemplacji. Widzenie Boga przez mnicha chrześcijańskiego było uwarunkowane posiadaniem „serca czystego”. Do tego stanu ducha prowadziła zaś pokora, dlatego mnisi pustyni mieli trudności z określeniem właściwego stanu ducha/serca, który umożliwiłby im dostąpienie łaski Bożych wizji ${ }^{20}$. Mnisi pojmowali, że ich ascetyzm nie gwarantował pewności doświadczanych wizji. Nie oczekiwali, że dzięki swym wysiłkom ascetycznym ujrzą w zamian Boga, gdyż wiedzieli, że ich serca nie są czyste, a myśli skutecznie blokują wizje. Ojcowie pustyni, świadomi swoich grzechów, odrzucali dążenia do wizji. Kolejnym z powodów ich odrzucania było „niedoświadczenie” czy „młodzieńczy zapał” do osiągania stanów ekstatycznych. Apoftegmaty z zasady pomniejszają znaczenie ekstaz, wizji czy snów. Mnisi egipscy nie pragnęli wizji przejściowych, ale dążyli do trwałej przemiany osoby (motyw dążenia do „chwały Adama przed upadkiem” czy „chwały niebieskiej w zmartwychwstałym ciele”). Jej realizacja wymagała stałego zdeterminowania i koncentracji, pokory i zdolności przebaczania ${ }^{21}$.

Jak podkreślał Antoine Guillamont, pierwsi mnisi chrześcijańscy podchodzili do wszelkich widzeń z dużą nieufnością i uważali raczej, że nawiedzał ich zły duch niż sam Pan Bóg czy aniołowie. Teksty apoftegmatów ukazują zdaniem tego badacza pierwotnego monastycyzmu egipskiego i syryjskiego pewnego rodzaju uchylanie się od wizji mistycznych. Nie negują ich, bo celem mnicha było poszukiwanie sposobu widzenia Boga, ale nie lubią uwypuklać tych widzeń czy ekstaz jako pierwszoplanowych na drodze do Boga. To dlatego opisywani

${ }^{20}$ Por. A.-J. Festugière, Mystique païenne et charité, [w:] A.-J. Festugière, L'enfant d’Agrigente, Paris 1950, s. 127-133.

${ }^{21}$ Por. W. Harmless, Chrześcijanie pustyni, s. 278-282. 
mnisi uznawali widzenia za specjalny charyzmat Boży, udzielany niewielu $\mathrm{z}$ nich, lecz niezbyt chętnie mówili o doznawanych ekstazach czy wizjach mistycznych. Jeśli cokolwiek z nich ujawniali, to były to jedynie fragmenty widzeń, które mogły służyć zbudowaniu czy poprawie innych mnichów, lecz większość z doznawanych wizji ukrywali przed innymi czy zbywali milczeniem. Jeśli już gdzieś owe widzenia były opisywane, to w utworach hagiograficznych (np. Żywot Antoniego czy Żywot Pachomiusza - wersja bohairska). Opisy owych wizji zamieszczone we wspomnianych hagiografiach nie pochodziły już od samych wizjonerów (życiowo - niezmiernie dyskretnych), ale od rozgadanych hagiografów. Ci ostatni chcieli wychwalać świętego, nadać danej osobie swoistą godność (szczególnie, kiedy chodziło o następcę danego świętego jako przełożonego monasteru), gdy chcieli zbudować swych czytelników czy nadać swym opowiadaniom wymiar dydaktycznego moralitetu, poświadczonego wizją z życia pozagrobowego (tzw. wątek dusz w zaświatach w zależności od stopnia ich ziemskich przewin). Hagiografowie dodawali więc do owych wizji wiele cudownych obrazów, pochodzących zich własnej fantazji. Dlatego sami mnisi podchodzili $\mathrm{z}$ dużą rezerwą do wizji, nie zaprzeczali ich istnieniu, ale sugerowali trudności, jakie napotykamy, próbując poznać ich treść. Bardziej prawdopodobne były za to opisy doświadczeń mistycznych pozostawione przez samego wizjonera (np. opisy Ewagriusza z Pontu, pisma Makarego, teksty Symeona Nowego Teologa). Ewagriusz akcentował, że widzenia miały miejsce rzadko, występowały pod koniec długiego, samotnego procesu oczyszczenia duszy przez ascezę i kontrolę myśli. Podkreślał, że należy odrzucać widzenia w formie zmysłowej, zobojętniać się wobec wszelkiej ich postaci, by dojść do stanu modlitwy czystej. Należy uwalniać się od form czy wyobrażeń, gdyż demony wprowadzają do umysłu formy złudne (myśli, wspomnienia dawniej widzianych przedmiotów, a czasami wręcz złudne wyobrażenia samego Boga). Dlatego asceta stopniowo winien przechodzić od rzeczy stworzonych i widzialnych, do rzeczy niewidzialnych, a ostatecznie do mistycznej wizji Boga (Ewagriusz z Pontu, $O$ modlitwie 72,115 ). Wizja właściwa powinna zdaniem 
Ewagriusza pozostać wizją czystego światła, bez kształtów, związków myśli o przedmiotach zmysłowych czy hipotetycznego - zmysłowego wyobrażenia Boga. Trudnością Ewagriusza, którą pozostawił nierozstrzygniętą, był brak definicji, czym ma być owo czyste światło (intelektem, który widzi swoje światło? Światłem Trójcy Świętej oddziałującym na intelekt człowieka?) $)^{22}$.

Jedną z systematycznych prób oceny snów i wizji mistycznych z pozycji rozeznawania duchów dał Diadoch z Fotike. Jak słusznie zauważał, celem życia ascetycznego jest dojście do doskonałej miłości Boga i bliźniego (por. Łk 10,27), stąd wierzący nie powinien koncentrować się na doświadczeniach wizji czy snów. Jego zdaniem najlepiej wcale nie ufać tym doświadczeniom. Nawet gdyby były zesłane przez Boga, a wierzący by je odrzucił, to nie będzie to poczytane przez Boga za zło, gdyż Bóg wie, że wierzący odrzucił te wyobrażenia, aby uniknąć podstępów demonicznych (Sto rozdziałów o doskonałości duchowej 36). W kwestii oceny snów dokonał on rozróżnienia na te, które nawiedzają dusze w stanie miłości Bożej, oraz sny będące demonicznymi fantazjami. Te pierwsze nie przerażają duszy, lecz napełniają ją duchową radością, a gdy minie sen, dusza szuka tej radości. Natomiast sny demoniczne są zmienne, nie zachowują swej formy, gdyż ich celem jest oszukać duszę. Stąd te ostatnie są wypełnione nawoływaniami, groźbami czy przerażeniem. Po przebudzeniu są rozpoznane jako podstęp diabelski, gdyż smutek pochodzący $z$ dobrego snu jest łagodny i sprzyja wzrastaniu w pokorze. Odnośnie do wizji Diadoch uznawał za przesłaniem 2 Kor 5,7, że nie należy im ufać czy złudnie starać się o ich otrzymanie, gdyż podczas życia ziemskiego, które jest wygnaniem z raju, należy żyć wiarą a nie wizjami (Sto rozdziałów o doskonałości duchowej 36) ${ }^{23}$.

${ }^{22}$ Por. A. Guillaumont, Wizje mistyczne w chrześcijańskim monastycyzmie wschodnim, [w:] A. Guillaumont, Uźródeł monastycyzmu chrześcijańskiego, t. 1, ŹM 37, przekł. S. Wirpszanka, Kraków 2006, s. 189-204.

${ }^{23}$ Por. M.R. Jurando, Rozeznawanie duchowe, s. 86. 


\section{Aspekt subiektywny i obiektywny procesu rozeznawania duchów}

W opisie władzy rozeznawania duchów jako procesu poznawczego można wyróżnić aspekt subiektywny oraz obiektywny. Przejawem tego pierwszego, ocenianego przez antycznych ascetów jako coś negatywnego, byłaby postawa definiowana jako „własna wola” przekształcająca się stopniowo w „samousprawiedliwienie” $\mathrm{i}$,upieranie się przy własnej racji”. Natomiast za przejawy swoistej obiektywizacji postaw duchowych, widocznych w patrystycznych opisach władzy rozeznawania, można uznać praktyki „ujawniania myśli”, osąd innych - starszych, oraz praktykowanie pokory.

Własna wola. Starożytni asceci sygnalizowali, że jednym z głównych niebezpieczeństw w rozwoju duchowym człowieka jest postawa polegania wyłącznie na własnej woli, czyli wyłącznej miłości samego

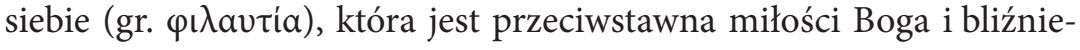
go. Postawa ta często była utożsamiana $\mathrm{z}$ „namiętnością”/, „nierozumnym uczuciem” względem ciała oraz negacją wartości duchowych [Maksym Wyznawca († 662), Księga miłości 2,8 ${ }^{24}$. „Własną wolę" rozumiano zatem jako podporządkowanie swych decyzji „namiętności”

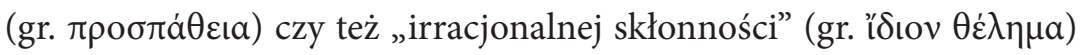
do podążania za tym, co sugerują umysłowi „złe myśli” (gr. oi kakol̀ $\lambda$ oүı $\left.\mu^{\circ}\right)^{25}$. Nie chodziłoby tu zatem ani o władzę wolnej woli jako

${ }^{24}$ Por. I. Hausherr, Philautie. De la tendresse pour soi à la charité selon saint Maxime le Confesseur, „Orientalia Christiana Analecta” 137, 1952.

${ }^{25}$ Od początków IV w. pojawiały się w ascetyce chrześcijańskiej swoiste listy wad głównych, które z czasem zaczęto definiować jako grzechy główne. Pierwotnie ascetom bardziej chodziło o naukę o złych myślach czy też o złych duchach zagrażających mnichowi niż o grzechach w sensie świadomego i dobrowolnego wykroczenia przeciw Bogu. Przyjmuje się, że Ewagriusz z Pontu († 399) jako pierwszy przedstawił systematyczny opis nauki o walce mnicha z ośmioma złymi duchami. W pismach Antirrheticus i De octo spiritibus malitiae mówi o walce przeciw duchom: obżarstwa, nieczystości, chciwości, gniewu, smutku, acedii, próżności i pychy. Ewagriuszowski katalog „ośmiu duchów” - „wad głównych” został prawie powszechnie zaakceptowany w świecie chrześcijańskim, a dzięki pismom Jana Kasjana nauka ta została rozpowszechniona także na 
taką, ani o wolność samą w sobie. „Irracjonalne skłonności” byłyby pragnieniami przeciwnymi prawdziwej naturze człowieka czy też prawdziwemu jego dobru. Kuszony owymi pragnieniami, człowiek wzmagałby „własną wolę” / „wolę cielesną”, która przekształcałaby się

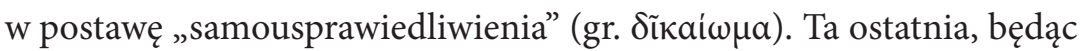
próbą swoistego auto-wytłumaczenia, odwoływała się czy to do wybranych fragmentów Pisma Świętego, czy myśli Ojców Kościoła, byleby tylko dać osobie złudzenie, że jest na właściwej drodze. Trwanie $\mathrm{w}$ samousprawiedliwieniu się przekształcało się następnie w postawę

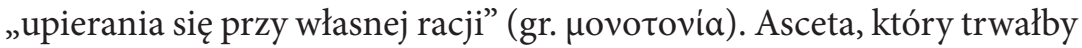
w takim uporze woli i myśli, zmierzał nieuchronnie do niedostrzegania swych wypaczeń i tłumaczył swe postawy pozorami gorliwości czy dobra. Stąd, aby nie upaść w postawę całkowitej subiektywizacji prze-

Zachodzie. Każda z wad przywodzących do grzechów otaczała się pomniejszymi wadami. Także i chciwość była przedstawiana jako matka, która rodzi i otacza się innymi grzechami (np. Jan Kasjan, Rozmowy z Ojcami 5, 2; tenże, Instytucje życia cenobickiego 7). W klasycznej dla Kościoła Zachodniego klasyfikacji grzechów głównych, podanej przez św. Grzegorza Wielkiego († 604), Moralia 31, 45, 87, pojawiła się jednak pewna modyfikacja. Święty Grzegorz, nawiązując do biblijnego tekstu z Syr 10,15 w wersji Wulgaty: „Pycha (superbia) jest początkiem każdego grzechu”, wyłączył ten grzech z katalogu Ewagriusza, gdyż potraktował go jako przyczynę pozostałych. Pycha została tu określona jako „korzeń wszelkiego zła. (...) Jej pierwszymi odroślami są: pusta chwała, zazdrość, gniew, smutek, chciwość, łakomstwo i rozwiązłość”. Grzegorz ograniczył zatem liczbę grzechów głównych do siedmiu, a w miejsce lenistwa wprowadził zazdrość. Według św. Grzegorza Wielkiego, Moralia 31, 45, 88: od chciwości pochodzi natomiast: „zdrada, defraudacja, fałsz, pogarda, niepokój, przemoc i zatwardziałość serca w czynieniu miłosierdzia”. Porządek grzechów ustalony przez św. Grzegorza Wielkiego obowiązywał do XII w., kiedy Hugon od św. Wiktora († 1141), De sacramentis christianae fidei 2, 13, 1 przywrócił pychę w miejsce próżności, a lenistwo w miejsce smutku. Od średniowiecza zaczyna się też mówić o wadach głównych jako o grzechach głównych, w sensie świadomego i dobrowolnego wykroczenia przeciw Bogu w materii ciężkiej. Na Wschodzie chrześcijaństwa natomiast zachował się oryginalny układ i liczba ośmiu wad głównych podana przez Ewagriusza z Pontu. Więcej na ten temat zob. L. Misiarczyk, Osiem «logismoi» w pismach Ewagriusza z Pontu, Kraków 2007. 
żyć duchowych, Doroteusz z Gazy (†620) postulował dla mnichów konieczność przewodnika duchowego (Nauki ascetyczne 4, 60) ${ }^{26}$.

Ujawnianie myśli (gr. غ̇łã $\gamma o ́ \rho \varepsilon v \sigma ı)$ ). Była to praktyka powiązana $\mathrm{z}$ rozróżnianiem i zwalczaniem złych myśli. Walka z myślami nie stanowiła celu samego w sobie, nie chodziło też o swoistą ascetyczną samorealizację, lecz o praktyczną realizację miłości bliźniego i stawanie się dojrzałym człowiekiem i chrześcijaninem. Mnisi powinni wyjawiać swe myśli temu, kto był „zdolny do przenikliwego rozróżniania” (gr.

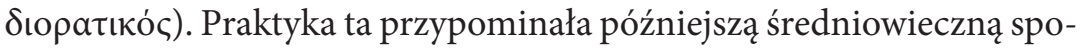
wiedź uszną, ale nie była to posługa sakramentalna. Od sakramentu pojednania ujawnianie myśli różniło się co najmniej trzema rzeczami. Mnich, któremu wyjawiano myśli, nie był najczęściej prezbiterem, liczyła się tutaj swoista mądrość duchowa wynikająca z praktyki życia wewnętrznego. Mnich, modląc się nad drugim mnichem wyjawiającym mu swe myśli, bardziej wstawiał się za nim, ale nie było to sakramentalne rozgrzeszenie czy jakakolwiek formalna modlitwa liturgiczna.

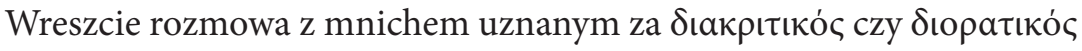
nie koncentrowała się na wyznawaniu grzechów głównych, zrywających przymierze z Bogiem (bo od tego, formalnie, przez cały okres patrystyczny była jednorazowa pokuta kanoniczna, łac. paenitenia secunda), ale skupiała się na wyznaniu „złych myśli”. Ojciec duchowy będący

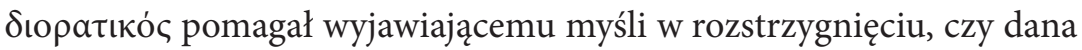
myśl była dobra czy zła, czy obojętna, czy należało postępować zgodnie z taką myślą, czy z nią walczyć lub też ją zignorować. Dlatego mnichom zalecano jak najczęstszą praktykę wyznawania myśli doświadczonym ascetom. Mówiono zatem o tej praktyce raz w tygodniu (abba Jan Karzeł, † 407) albo dwa razy w miesiącu (abba Pafnucy „Głowacz”, $\dagger$ IV w.), ale nagłe porady mogły mieć miejsce doraźnie, nawet kilka

${ }^{26}$ Por. T. Špidlik, L’obéissance et la conoscience selon Dorothée de Gaza, „Studia Patristica” XI (1972), TU 108, s. 72-78; T. Špidlik, I. Gargano, Duchowość ojców greckich i wschodnich, przekł. J. Dembska, Kraków 1997, s. 105-106. 
razy w ciągu nocy. Natomiast studytom zalecano wyjawianie swych myśli własnym przełożonym codziennie ${ }^{27}$.

Osąd innych - starszych. Celem obiektywizacji procesu rozpoznawania duchów i kształtowania w mnichu tej władzy poznawczej pojawiały się napomnienia ascetyczne, by asceta, jeśli chce dojść do rozeznawania duchów rozumianego jako cnota, nie ufał własnemu osądowi, lecz szukał rady u starszych i bardziej doświadczonych. Istotną

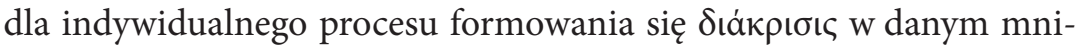
chu była zatem wspólnota monastyczna, w której wzrastał. Środowisko ascetyczne sprzyjało kształtowaniu się swoistej pedagogiki duchowej, związanej $\mathrm{z}$ formowaniem postawy umiarkowania zarówno $\mathrm{w}$ zachowaniach, jak i w formułowaniu pouczeń z tym związanych. Dzięki wspólnemu życiu w cenobiach ascetycznych łatwiej dostrzegano (swoiste „przenikliwe wejrzenie w serce człowieka”) zagrożenia możliwymi oszustwami szatańskimi. Dopatrzono się też charakterystycznej prawidłowości w owych pokusach przeciwko umiarkowaniu: dla mnicha, który chciał wieść życie cnotliwe, oszustwa diabelskie stawały się bardziej subtelne, przez co mogły prowadzić do jeszcze poważniejszych upadków w grzech. Stąd napominano początkujących mnichów, by nie trwali w swych własnych, upartych sądach, bo wynikały one z niedoświadczenia (Jan Kasjan, Rozmowy II, 11, 7) ${ }^{28}$.

Postawa pokory. Kolejnym istotnym aspektem obiektywizacji procesu „rozeznawania duchów” było uwypuklenie wydawałoby się oczywistej prawdy pedagogicznej, że początkujący asceta nie rozumie od razu pouczeń duchowych, jakich udzielał mu starszy mnich. Stąd podkreślano praktyczną i wymierną rolę doświadczenia, które powinno doprowadzić początkującego ascetę do wiedzy duchowej. Zauważano też, że postawa krytykanctwa i odrzucania rad starszych prowadziła młodych i niedoświadczonych mnichów do pychy, zadufania we wła-

${ }^{27}$ Por. W. Harmless, Chrześcijanie pustyni, s. 262-265.

${ }^{28}$ Por. D. Kasprzak, Ojcostwo duchowe w myśli patrystycznej - zarys zagadnienia, „Polonia Sacra” 20(2016)3/44, s. 101-122; M.R. Jurando, Rozeznawanie duchowe, s. $78-80$. 
sne zdanie i paradoksalnie do odrzucania nawet najbardziej pożytecznych rad, gdyż niejeden nowicjusz uznawał te rady w swej pysze za zbyteczne czy szkodliwe (Jan Kasjan, Rozmowy 27, 3, 2). Dlatego, chcącym posiąść cnotę rozeznawania duchów, zalecano pedagogiczne przyjęcie postawy „pokory serca” czy też „pokory prawdziwego rozsądku”, będącej matką wszystkich cnót (Jan Kasjan, Rozmowy 24, 16) ${ }^{29}$.

\section{Wnioski}

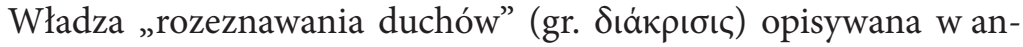
tyku chrześcijańskim zarówno jako cnota, jak i dar dotyczyła zatem całościowego rozwoju duchowego chrześcijanina. Odnośnie do prawd wiary władza rozeznawania duchów stawała się zdolnością rozeznawania prawdy i błędu w kwestiach wiary. Dar właściwego rozróżniana duchów dopomagał rozpoznawać dobro i zło, wskazywał na ukryte źródła grzechu, dopomagał w oczyszczeniu umysłu ze złych myśli, namiętności i skłonności. Jako rozsądek i roztropność sugerował właściwe wybory życia codziennego. Jako umiarkowanie sapiencjalnie wskazywał na właściwe wyznaczanie czasów postu czy rekreacji. Stosowne rozeznawanie w codziennych wyborach prowadziło do osiągnięcia we-

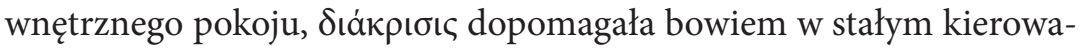
niu się rozwagą i postępowaniem zgodnym z naturą. Przy duchowym prowadzeniu ucznia władza rozeznawania duchów ściśle łączyła się z duchową odpowiedzialnością za postępującego na drodze ascezy. Jej

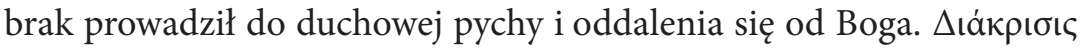
była zatem postrzegana jako duchowy wyznacznik umiaru. Wydaje się, że niezależnie od postępu współczesnych nauk o człowieku, wskazówki antycznych mnichów mogą dalej być pomocne dla wierzącego w rozróżnianiu tego, co złe, od tego, co dobre, na drodze jego spotkania z Bogiem.

${ }^{29}$ Por. M. R. Jurando, Rozeznawanie duchowe, s. 77-79; M. Szram, Cnota pokory w nauczaniu greckich Ojców Kościoła IV wieku, Lublin 2014. 


\section{Summary}

Two basic narratives concerning the problem of the power of "di-

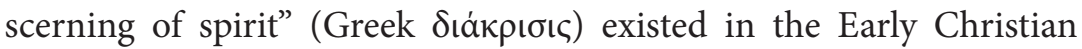
Church. The first one dates back to the period of development of the charismatic monastic life, the second one to the period of its ancient institutionalization. Both converge in their conclusions however, they seem to differ in the perception of the nature of the power of discernment. The first one regarded the "discerning of spirit" as a gift/charism,

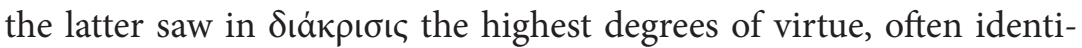
fied with a gift. It also seems that regardless of the development of the monastic tradition the power of spiritual discernment was most of all related to the personal sanctity of the discerner. The power of "discerning of spirit" is described in Christian antiquity as both a virtue and gift and concerned with the overall spiritual development of the Christian. Its absence is understood to lead to pride and vanity and only

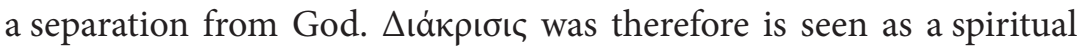
determinant of temperance.

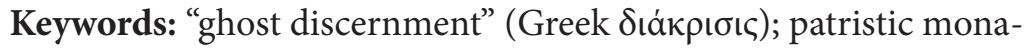
sticism; spiritual moderation

\section{Bibliografia}

Allison D.C., The Authorship of 1 QS III,13-IV,14, „Revue de Qumrân“ 38(1980), s. 256-268.

Atanazy z Aleksandrii, Żywot św. Antoniego, Źródła Monastyczne 35, przekł. E. Dąbrowska, Kraków 2008, s. 75-146.

Colombás G.M.B., Discernimento degli spiriti (diacrisis), [w:] Dizionario degli Istituti di Perfezione, vol. III, red. G. Rocca, Roma 1976, s. 705-706.

Dautzenberg G., Zum religiongeschichtlichen Hintergrund der «diakriseispneumaton» (1 Kor 12,10), „Biblische Zeitschrift“ 15(1971), s. 93-104. 
Duhaime J.L., L'instruction sur les deux esprits et les interpolations dualistes à Qumrân (1 QS III,13-IV,26), „Rivista Biblica“ 4(1977), s. 566-594.

Festugière A.-J., Mystique païenne et charité, [w:] A.-J. Festugière, Léenfant d'Agrigente, Paris 1950, s. 127-133.

Fredrikson N.I., L'esprit saint et les esprits mauvais dans le Pasteur d'Hermas: sources et prolongements, „Vigiliae Christianae” 55, 3(2001), s. 262-280.

Guillaumont A., „Serce” u starożytnych greckich pisarzy ascetycznych, [w:] A. Guillaumont, U źródeł monastycyzmu chrześcijańskiego, t. 2, ŹM 38, przekł. S. Wirpszanka, Kraków 2006, s. 83-99.

Guillaumont A., Nauczanie duchowe egipskich mnichów. Kształtowanie się tradycji, [w:] A. Guillaumont, U źródeł monastycyzmu chrześcijańskiego, t. 2, ŹM 38, przekł. S. Wirpszanka, Kraków 2006, s. 101-115.

Guillaumont A., Wizje mistyczne w chrześcijańskim monastycyzmie wschodnim, [w:] A. Guillaumont, U źródeł monastycyzmu chrześcijańskiego, t. 1, ŹM 37, przekład S. Wirpszanka, Kraków 2006, s. 189-204.

Harmless W., Chrześcijanie pustyni. Wprowadzenie do literatury wczesnego monastycyzmu, przekł. M. Höffner, Kraków 2009.

Hausherr I., Philautie. De la tendresse pour soi à la charité selon saint Maxime le Confesseur, „Orientalia Christiana Analecta” 137, Roma 1952.

Hausherr I., Spiritual Direction in the Early Christian East, Kalamazoo (MI) 2010.

Jurando M.R., Rozeznawanie duchowe. Teologia. Historia. Praktyka, przekł. K. Homa, Kraków 2002.

Kasprzak D., Ojcostwo duchowe w myśli patrystycznej - zarys zagadnienia, „Polonia Sacra” 20(2016)3/44, s. 101-122.

Lampe G.W.H., A Patristic Greek Lexicon. With Addenda et Corrigenda, Oxford 1991.

Liddell H.G., Scott R., Greek-English Lexicon. With a Revised Supplement, Oxford 1996.

Lienhard J.T., On "Discernment of Spirits" in the Eearly Church, „Theological Studies" 41/3(1980), s. 505-529.

Lies L., Die Lehre der Unterscheidung der Geister bei Origenes und Ignatius von Loyola, „Origeniana” 7(1999), s. 717-732.

Misijuk W., Przewodnictwo duchowe w monastycyzmie prawosławnym, Lublin 2014.

Munzinger A., Discerning the Spirits. Theological and Ethical Hermeneutics in Paul, Cambridge 2007. 


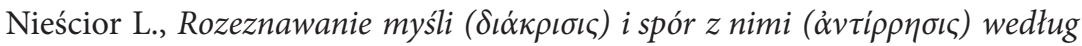
Ewagriusza z Pontu, [w:] Droga doskonałości chrześcijańskiej w epoce patrystycznej. Zagadnienia wybrane, red. J. Pałucki, M. Szram, Lublin 1997, s. 31-56.

Pietras H., Rozeznawanie duchów u Ojców Kościoła, [w:] Rozeznawanie duchów w «Ćwiczeniach duchownych», red. K. Osuch, Czechowice-Dziedzice 1991, s. 60-67.

Pietras H., Rozeznawanie duchów u Orygenesa, „Życie Duchowe” 39(2004), s. $113-116$.

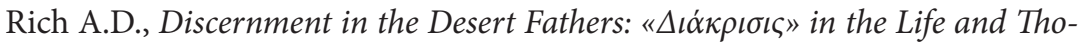
ught of Early Egyptian Monasticism, Milton Keynes (UK) 2007.

Špidlik T., Duchowość chrześcijańskiego Wschodu. Przewodnik systematyczny, przekł. L. Rodziewicz, Kraków 2005.

Špidlik T., Gargano I., Duchowość ojców greckich i wschodnich, przekł. J. Dembska, Kraków 1997.

Špidlik T., Lobéissance et la conoscience selon Dorothée de Gaza, „Studia Patristica” XI (1972), TU 108, s. 72-78.

Szram M., Cnota pokory w nauczaniu greckich Ojców Kościoła IV wieku, Lublin 2014. 
